\title{
Redefining Career Communities in Higher Education
}

\author{
June Y. Lee ${ }^{1} \&$ Sheetal Patel ${ }^{2}$ \\ ${ }^{1}$ Assistant Professor, Department of Entrepreneurship, Innovation, and Strategy, School of Management, University \\ of San Francisco, CA, USA \\ ${ }^{2}$ Career Content Lead, Career Management Center, Graduate School of Business, Stanford University, Stanford, CA, \\ USA
}

Correspondence: June Y. Lee, University of San Francisco, CA, USA. E-mail: june.lee@usfca.edu

Received: July 17, 2019

doi:10.5430/ijhe.v8n5p1
Accepted: July 30, 2019

Online Published: July 31, 2019

\begin{abstract}
This study aims to revisit the understudied concept of career communities in higher education. Using mixed methods, this study assesses how university students define and characterize career communities compared to general communities. Based on our interviews $(\mathrm{N}=25)$ and survey $(\mathrm{N}=123)$, we define a career community more narrowly as a group of individuals who share similar career interests or aspirations and where one can receive direct or indirect customized benefits through the exchange of knowledge, expertise, and resources. Theoretical and practical implications with future research opportunities have been recommended for researchers and practitioners in higher education.
\end{abstract}

Keywords: career communities, career services, career center, university, higher education

\section{Introduction}

Creating community is an important aspect of higher education (McCarthy, Pretty, \& Catano, 1990; Spanierman et al., 2013). University career services, however, have largely been based on an individual counseling model. As a field of higher education and typically housed within student affairs, university career services have been looking at new models for implementation to address the growing needs of students, scale, and changes in the field (Lee \& Patel, in press; Young, 2016). One framework in particular that has gained popularity is career communities (Contomanolis et al., 2015; Dey \& Cruzvergara, 2014). While creating career communities may make sense, theoretical and practical understanding of this concept is still needed.

Community-oriented university career services could help students connect with the different stakeholders needed to find meaningful work opportunities that utilize their education and skills. Such services could also help students find value in attending university institutions (Allan et al., 2017; Lee \& Patel, in press; Steger et al., 2012). This study aims to contextualize career communities by defining them and examining what characteristics are associated with them compared to those of general communities. Such comparison is undertaken especially in relation to student affairs communities, which are an essential piece of higher education and student affairs work. We further scholarly research on communities and career communities as well as provide recommendations for practitioners and higher education leaders.

\section{Theoretical Framework}

\subsection{Social Learning Theory}

Social learning theory provides a theoretical framework to highlight the importance of community in one's learning. A social perspective of learning shifts attention from processing information to the processes of participation and interaction that sustain the real context for learning (Gherardi et al., 1998, p. 277). The focus thus transfers from individual learning to learning as participation in a social world (Lave \& Wegner, 1991, p. 43) and that involves a community. "Learning, in short, takes place among and through other people" (Gherardi et al., 1998, p. 274). Thus, learning is "situated" (Lave \& Wegner, 1991) and is an integral part of the generative social practice in the lived-in world. Researched by Lave and Wegner (1991), communities of practice represent an area of scholarship that relates to learning through a community (Lave \& Wegner, 1991). Learning is a cognitive process that takes place in a particular social, cultural, or institutional context, and it happens not only through direct experiences but also through 
indirect experiences such as observation (Lave \& Wagner, 1991). Lave and Wenger (1991) posit that learning can occur socially and through relationships, otherwise known as "communities of practice." Learning can exist everywhere, including at home, work, school, and neighborhoods, and its main constructs include a joint-enterprise engagement that includes a social component and the production of a shared capability. These communities are created over time through a shared pursuit of knowledge via a particular activity. Most importantly, there are members who share a practice and activity as opposed to merely an interest (Lave \& Wagner, 1991; Wenger, 1998).

\subsection{Sense of Community}

Different types of communities have been defined as well. The term "communities" and its constructs have been studied by scholars (McMillan \& Chavis, 1986; Lave \& Wagner, 1991), and reviewing previous literature can help create context and an initial definition of a career community. Common constructs across different types of communities are evident in the previous literature. For example, "sense of community" is a feeling that members have of belonging, they matter to one another and to the group, and their needs will be met through their commitment to be together (McMillan \& Chavis, 1986). Per McMillan and Chavis (1986), four characteristics contribute to a sense of community: membership, influence, integration and fulfillment of needs, and shared emotional connection. First, membership refers to the feeling of belonging, which can be created from boundaries, emotional safety, identification, personal investments, and a common system of symbols. Boundaries can be formal or informal, direct or indirect, and physical or conceptual, wherein people either do or do not become members. Emotional safety refers to creating trust and a sense of safety between members, and identification implies that members feel as though they "fit in" with other community members. Personal investment includes dedicating time, knowledge, skill, and sharing, and a common symbol such as a mascot, logo, brand, or slogan also enhance the notion of membership (McMillan \& Chavis, 1986). The second characteristic is influence. Members have influence over the way their community is being developed, and the community also influences the way its members interact with each other. The third characteristic of membership is integration and fulfillment of needs, whereby members obtain and fulfill the desires and wishes of their communities by joining them in the first place. The final characteristic is shared emotional connection. Members share a history of experiences, which elicits positive or negative emotional connections among them (e.g., feelings of reward, achievement, or resilience). This emotional connection is powerful and long-lasting and develops stronger bonds among members. The resulting "connectedness" (Resnick et al., 1997) or "belongingness" (Baumeister \& Leary, 1995) is the most critical and fundamental characteristic (Schaps, 2003) related to community.

For the purposes of this paper, we begin with the following broad definition: a career community refers to any formal or informal groups that bring together individuals (along other with stakeholders, if appropriate) with shared career-related interests and goals, who interact for a fixed duration based on their agreed purpose (Contomanolis et al., 2015). For instance, a career community could be an informal study group that students self-organize to prepare for case study interviews in the management consulting industry. It might also be alumni mentoring programs organized by a career center to match a student with the alumnus/alumna in their chosen career. However, the literature thus far has focused on general learning communities for students and, within careers, communities where members are already part of the workforce. To narrow the focus of a career community within higher education, we aim to narrow these definitions.

RQ1: How do students define career community in the context of higher education?

\subsection{Different Communities in Higher Education}

The notion of community has been emphasized in the context of higher education and student affairs (Battistish \& Hom, 1997; DeNeui, 2003; Warner \& Dixon, 2011; 2013). For instance, numerous studies have demonstrated that creating and participating in a learning community, which is defined as "some formal program where groups of students take two or more classes together" (Zhao \& Kuh, 2004), substantially helps students stay more engaged in other educationally effective activities compared to those students who have not participated in such a community (Lenning \& Ebbers, 1999). Per Lenning and Ebbers (1999), learning communities have two critical dimensions: membership and primary form of interaction. Rather than having a direct impact on student learning, participation in a learning community leads to a greater set of positive educational outcomes, including greater interaction with peers and faculty members. These outcomes could lead to improved student learning in the long run.

Within the organizational culture literature, the idea of an occupational community has also been referenced (Van Maanen \& Barley, 1984). In this case, the theorists posit that occupational communities are "an organizational frame of reference for understanding why it is that people behave as they do in the workplace (Van Maanen \& Barley, 1984: 289-290)." Similar to other communities, people in occupational communities share similar values and interests. 
However, this type of community is defined as a group of people who consider themselves to share the same type of work, identify with such work, share a set of norms in relation to work and perhaps other components of life, and have social relationships that help meld work and leisure.

Lastly, the term career community has been used to describe "self-organizing, member-defined social structures through which [individuals] draw career support" in the context of organizational behavior literature (Parker et al., 2004: 489). The studies following such a definition were mainly focused on community members already well into their careers. They also posit that career communities help members understand knowing-why, knowing-how, and knowing-whom when it comes to careers (Parker et al., 2004). Different types of communities are set forth, including those based on company, industry, region, ideology, and others. Outcomes from participation have included career support, sense-making, and learning.

Given previous literature on the concept of community, this study investigates what students value in career communities compared to the following four factors that help foster a sense of community: membership, influence, integration and need fulfillment, and shared emotional connection. What are different attractive characteristics of a community, especially a "career community?"

RQ2: What characteristics of a career community do university students identify that might differ between communities in general versus specific career contexts?

\section{Methodology}

In this study, we use a sequential mixed-methods approach where we first conduct a series of focus groups and interviews. We then follow up with a survey to define a career community (RQ1) and understand associated characteristics of a career community (RQ2). An exploratory qualitative phase allows different themes and patterns to emerge which can be further tested quantitatively through a survey (Creswell, 2009).

\subsection{Study Design and Sample}

\subsubsection{Focus Groups and Interviews Participants}

In phase one, focus groups composed of students $(N=18 ; 6$ undergraduates and 12 graduates; 10 females) were undertaken at a private university on the West Coast of the US. Participants were given an incentive of USD \$10. In phase two, seven key informant interviews were conducted with campus community leaders. Through their daily roles and responsibilities, these key informants served as experts in creating community and interacted with students in their own domain (e.g., LGBT Community Center, Black Community Services Center, Asian American Community Center). They were not monetarily compensated.

\subsubsection{Survey Participants}

Based on the findings from the focus groups and interviews, a survey was designed and distributed online to a wider student population for triangulation. The invitation to participate in an online survey was sent out through the university career services monthly newsletter. Participants included a sample of 123 students. Refer to Table 1 for a survey demographics summary. Respondents were $45 \%(n=55)$ female, $34 \%(n=41)$ international students, and $63 \%$ on-campus residents. The age ranged from 18 to $40(M=24.5, M d n=24)$. Half of the participants $(n=61)$ were Asian, $27 \%$ white, $15 \%$ undeclared or prefer not to state, 3\% Hispanic or Latino, $1 \%$ Black or African American, $1 \%$ Native American, and 4\% Others. All focus group, interview, and survey participants were told directly during recruitment what the study was about and consented in accordance with the university's institutional review board approval. 
Table 1. Survey Demographics Summary (N=123)

\begin{tabular}{llllll}
\hline Gender & Percentage & Age & Percentage & Ethnicity / Race & Percentage \\
\hline Male & $53 \%$ & $18-20$ & $13 \%$ & Asian or Pacific Islander & $50 \%$ \\
Female & $45 \%$ & $21-25$ & $41 \%$ & Black or African American & $1 \%$ \\
Undeclared & $2 \%$ & $26-30$ & $27 \%$ & Hispanic or Latino & $3 \%$ \\
Total & $100 \%$ & $31-35$ & $7 \%$ & Native American or Indian American & $1 \%$ \\
& & $36-40$ & $1 \%$ & White & $27 \%$ \\
Year & Percentage & Undeclared & $12 \%$ & Other & $4 \%$ \\
Freshmen & $5 \%$ & Total & $100 \%$ & Undeclared & $15 \%$ \\
Sophomore & $6 \%$ & & Total & $100 \%$ \\
Junior & $2 \%$ & International & Percentage & & Percentage \\
Senior & $2 \%$ & Yes & $34 \%$ & Live on-campus & $63 \%$ \\
Master & $31 \%$ & No & $59 \%$ & Yes & $32 \%$ \\
Doctorate & $47 \%$ & Undeclared & $7 \%$ & No & $5 \%$ \\
Postdoc & $1 \%$ & Total & $100 \%$ & Undeclared & Total \\
Other & $1 \%$ & & & & $100 \%$ \\
Undeclared & $6 \%$ & & & &
\end{tabular}

\subsection{Procedures}

\subsubsection{Interview Protocols}

One of the authors moderated the focus groups and interviews, which took place on campus and lasted 60 to 90 minutes. All sessions were semi-structured. Participants were told sessions were being audio-recorded. The questionnaire guides for the focus groups and interviews assessed the following concepts from the perspective of students: (a) definition and characteristics of general and career communities; (b) examples of communities; and (c) written exercise to list and rank the most important characteristics of a career community.

\subsubsection{Survey Measures}

The survey was distributed via weekly newsletter by career services and various departments. This survey included three sections: (a) open-ended questions for definition of general and career communities; (b) characteristics associated with both types of communities; and (c) demographics. In Part (a), we asked students to provide examples of their general and career communities. Upon completion, students received USD \$5 for 15 minutes of their time.

\subsection{Analysis}

\subsubsection{Responses from Focus Groups and Interviews}

This study used descriptive coding, where the researchers relied primarily on the participants' words for meaning and avoided behind-the-scenes interpretation (Lindlof \& Taylor, 2002). To create a codebook and systematically analyze the transcribed interviews and focus groups, the authors started with a list of codes based on the literature review. This codebook was semi-structured such that any new discovery of patterns or themes would be added to or updated in it. The unit of analysis was the code-associated response the participant mentioned. During this process, two researchers reviewed and discussed the work regularly to resolve any discrepancies that emerged.

\subsubsection{Survey Responses}

Using R software, we first performed a descriptive analysis based on the completed responses. We then focused on the open-ended questions to parse through any patterns and themes between general and career communities through descriptive coding. 


\section{Results}

\subsection{Definition of Career Community (RQ1)}

RQ1 asked how participants define a career community. To see different angles of the definition, the focus groups, interviews, and survey asked participants to define "community" and, separately, "career community." Participants were also asked for examples of each. In both cases, participants defined communities by listing their characteristics. Based on the interviews and focus groups, a "community" was defined very broadly and was based on one's social, cultural, and institutional experiences. For instance, a student interviewee stated a career community is "a group of people with some sort of shared identity. It could be based on where you are from, what you do, but also what you are trying to do."

Participants often referred to members. Examples ranged from family and classmates to co-workers to university alumni, and the different groups mentioned serve different purposes. The themes for this definition included a group of individuals forming a community for a specific purpose. "An example of a community would be a group of international students here on campus. Because we're international students, we face similar challenges living in the U.S., so we have lots of things in common" (Student).

Survey responses confirmed these patterns that "community" was a group of individuals who share common goals, interests, and purpose. When defining a community, $75 \%$ of the total survey participants used the word "people," and $37 \%$ used the word "common." The next frequently appearing words were "interest (33\%)," "share (28\%)," "similar $(13 \%)$," and goal (11\%)." Further coding showed that a general community is more widely defined, ranging from family members to classmates to ethnic groups on campus. "A community is a group of people [who] share similar interests, goals, background, or characteristics" (Student). Another student interviewee stated, "Having a common goal is something that makes a community last in [the] long run. This is very important. At least in the beginning, you don't know the people in a community, so that's what bring[s] everyone together. Afterwards, it might be the people that make you stay."

Based on the focus groups and interviews, career communities were more narrowly defined in three ways. First, not surprisingly, a career community had specific membership and purpose: a group of individuals who share similar career interests or aspirations. "I would first look to see if we share some common interests. We can agree on some issues and disagree on others, but as long as we are brought together for a common career interest, I would consider joining that community" (Student). Another pattern related to membership was a desire for personalization and exclusivity. For instance, a student interviewee elaborated, "I don't want to feel like it is a community for everyone. I want to feel like my career community is customized and specialized and tailored for people like me or people with similar interests [to mine]. A career community should be a specialist, not a generalist" (Student).

Additionally, the positive results needed to be evident from the community. These results can be in the form of direct or indirect benefits (i.e., finding an internship or a job, growing a professional network), the success of other members, or even the reputation of a career community. In other words, purpose was also determined by the results of previous members. For example, one student interview said, "I really need to see [the] success of other community members to know that it is worth joining and there is something that I can get out of it." Another interviewee stated, "A career community should be functional. If it is not beneficial, a career community would not work. It must demonstrate results." This was echoed by many student interviewees. "If I am not benefitting from my career communities, I don't know why I would spend any time in them. I will just hang out with my social communities. I expect practical benefits and results" (Student).

Second, a career community was often defined as having a social structure with a hierarchy and information asymmetry. This framework allows members to exchange knowledge and resources. Participants were more focused on obtaining resources from others as opposed to how well they get along and interact with their community members. A student interviewee said, "People who are professionally trained and have deep understanding around my research topics whom I can understand and who can understand me." Another stated it is "a group of people who are all looking for jobs that have something in common, and using that fact to drive each other. For example, we come in and do work together, check in regularly to help and support each other. Have you made progress? How did it turn out? Did you apply? How to evaluate offers? Refer each other. For example, 'Hey, I went through interviews with a certain company, so I can help you and provide advice"” (Student).

Third, students defined career communities as opportunities to gain knowledge they could not find online. For instance, "There is so much information out there online, and sometimes, you find it more efficient to just look for information online rather than showing up to an event. For me, a career community needs to offer something on top 
of that; it must significantly increase my chance of finding a career. I don't know what that is anymore... Giving information at a career community is not enough because you need extra effort to find out if a career community is meeting, when and where, and [to] be there" (Student).

While $40 \%$ of survey participants used the word "people" and $25 \%$ used the word "interest" when defining a career community, the next most frequently appearing words were "professional" at $17 \%$, "help" at $17 \%$, "work" at $16 \%$, and "share" at $15 \%$. Other constructs were opportunity, support, advice, network, skill, develop, and academic, all at less than $10 \%$. Open-ended coding also supported the notion that a career community is narrowly defined with the three themes seen in the qualitative data.

1) Purpose: "People who share the same career interests [whom] you can go to for guidance and advice. These people went through similar experiences that can help you understand what it is you need to do" (Student).

2) Information exchange: "Either people who have the same professional interests or research backgrounds or people who have different experiences with interest in one's own research. By interacting and asking and responding to questions about research or career opportunities (either one's own or someone else's), the shared knowledge can benefit both parties and help inform both career decision and direction" (Student).

3) Knowledge not found elsewhere: "An event or activity focused on professional and intellectual development. Many of the conversations I have with people in my career community are focused on research and potential jobs rather than on personal matters like relationships or family" (Student).

\subsection{Characteristics of Career Community (RQ2)}

The second research question asked what characteristics of a career community students could identify that might differ from that in a general community. During the qualitative sessions, participants answered this question verbally but also had the opportunity to list characteristics and rank their top five. They could do this for both general and career communities and then provide a debriefing on their answers. In the survey portion, participants had the chance to list characteristics and rank their top five from lists given to them based on the qualitative data.

The top three characteristics identified in the qualitative data for general communities were sense of belonging (including identify and fit), common goals/purposes, and membership. Others mentioned included emotional safety/trust and locations/proximity. Table 2 provides definitions and quotes for the top characteristics of general communities. "As a part of a larger group of people with a common interest, you feel part of something greater than yourself. You feel like you can greater serve that interest in a group, a community, rather than on your own" (Student). 
Table 2. Top Five Preferred Characteristics of General Communities

\begin{tabular}{ll}
\hline Characteristics & Participant Quotes \\
\hline Sense of & "I just took a qualifying exam, so we had a study group \\
Belonging (Fit \& & together that met twice a week. When I studied by myself, I \\
Identify) & felt very depressed and felt like I was the only person \\
& failing and struggling. When I started to study together, we \\
& were helping each other to explain things that we did not \\
& know because we know not everyone knows everything. So \\
& we felt like we belonged together. In bad times, they were \\
& giving me hugs and cheering for me, and that helped me" \\
& (Student).
\end{tabular}

\section{Definition}

The conception, qualities, beliefs of oneself and feeling of how much one fits well into a given community

Common Goals, "A goal has to exist even if it is as simple as let's go watch Purposes, Interests, Experiences a movie. Having a purpose matters. It can only strengthen a community. From that, you can take it beyond that and talk more about how it is impacting you and the group. From that, you can build a relationship and learn something from each other. From that, you can establish connections" (Student).

Members/
Membership

"Membership makes a difference. You should have consistency and a similar level of commitment among members. This is also related to sense of identity and belonging. People are the ones that create sense of belonging" (Student).

Emotional Safety "If I feel emotionally down, I will turn to my close friends and Trust or my acapella group, because they are non-judging. If I want to go party, I will go to my [dorm] row house. Depending on my emotions, I choose which community to spend time with" (Student).

Accessibility and Proximity
One's desired mission and results by joining a community

People or experiences with people in a given community

Idea of being protected and comfortable in a community

Community or its members being available when needed; emotional or physical closeness
"Having easy access to and being in close proximity is very important. Otherwise, you feel disconnected and detached. I even hesitate to include any groups that are far away as part of my community. When considering joining, it is even more important" (Student).

Survey participants were asked to rank in order the characteristics of general communities found from the qualitative study $(1=$ top-ranked characteristic): sense of belonging (including identity and fit), common goals/purposes, membership, emotional safety/trust, and accessibility/location. Results indicated that $44 \%$ of the survey participants ranked sense of belonging as the most important and valuable for general communities, and $87 \%$ placed it in their top three. Moreover, $24 \%$ of the survey participants ranked common interests as number one, with $83 \%$ putting it in their top three. Membership was ranked as number one by $18 \%$ of the survey participants, and $52 \%$ included it in their top three. Emotional safety/trust was ranked as the top characteristic by $11 \%$ of the survey participants, with $33 \%$ placing it in their top three. Location/accessibility was slightly more emphasized in our in-person interviews and focus groups; $2 \%$ ranked it as their number one characteristic, while 30\% put it in their top three.

When characterizing a career community, several distinct themes emerged. First, in such a community, benefits must be clearly stated or demonstrated. It is not sufficient that members feel a sense of belonging and share common goals/purposes. "Career community is a community that aims to impact and/or benefit members' career progression 
and/or selection" (Student).

Second, resources and information must be relevant and specific for a career community to be considered valuable. As resources and information become more accessible through the Internet, offline career communities must especially be more relevant to hold their merits. "Someplace which gives me useful advice where I can learn from a formal mentor or my peers... a structured organization that provides help and support" (Student).

Lastly, expertise and knowledge exchange must exist within a career community for participants to join it. "A community that is able to help you advance professionally, develop your skills, talk about problems you are having, and give suggestions on how to proceed" (Student). Table 3 provides definitions and quotes for the top characteristics of career communities.

Table 3. Top Five Characteristics of Career Communities

\begin{tabular}{|c|c|c|}
\hline Code & Examples & Definition \\
\hline Benefits & $\begin{array}{l}\text { "If I am not benefitting from my career communities, I don't } \\
\text { know why I would spend any time (there). I will just hang out } \\
\text { with my social communities. I expect practice benefits and } \\
\text { results" (Student). }\end{array}$ & $\begin{array}{l}\text { Expected values and } \\
\text { outcomes by joining a } \\
\text { career community }\end{array}$ \\
\hline Relevance & $\begin{array}{l}\text { "Demonstrating common interests and speaking the same } \\
\text { language is important. For example, I am an art history major, } \\
\text { and I started to look for jobs in computer graphics, I realized it } \\
\text { is hard to get people's attention if I do not demonstrate } \\
\text { sufficient interests or speak their language" (Student). }\end{array}$ & $\begin{array}{l}\text { Degree with which } \\
\text { resources and } \\
\text { information are } \\
\text { aligned to one's career } \\
\text { field of interests }\end{array}$ \\
\hline Expertise & $\begin{array}{l}\text { "For career communities, having knowledge of what a specific } \\
\text { career entails are important for how to prepare interviews, } \\
\text { recruiting process, closing interviews, offers, etc." (Student). }\end{array}$ & $\begin{array}{l}\text { Expert knowledge or } \\
\text { skills in one's career } \\
\text { field or interests }\end{array}$ \\
\hline $\begin{array}{l}\text { Specialized } \\
\text { and } \\
\text { Customized } \\
\text { Information }\end{array}$ & $\begin{array}{l}\text { "Expertise and specialized information are my top two choices } \\
\text { because I am not job searching anytime soon, so I am not } \\
\text { seeking to have emotional connections or shared feelings with } \\
\text { experts in my field. That will play a greater role as I start job } \\
\text { searching after a few years. For now, I just want to know what } \\
\text { they are doing for my information" (Student). }\end{array}$ & $\begin{array}{l}\text { Filtered and } \\
\text { personalized } \\
\text { information to one's } \\
\text { career field of } \\
\text { interests }\end{array}$ \\
\hline $\begin{array}{l}\text { Success of } \\
\text { Other } \\
\text { Members }\end{array}$ & $\begin{array}{l}\text { "If you consider university as one community, reputation is } \\
\text { important. Being a member of a prestigious university is } \\
\text { important. In my personal life, reputation does not matter } \\
\text { much. For academic and career-related communities, a good } \\
\text { reputation is very important... Hopefully, good reputation } \\
\text { entails relevant and specialized knowledge and good people" } \\
\text { (Student). }\end{array}$ & $\begin{array}{l}\text { Examples of positive } \\
\text { outcomes by joining a } \\
\text { career community }\end{array}$ \\
\hline
\end{tabular}

On the survey, based on the list of characteristics aggregated from the focus groups and interviews, participants were asked to rank their top five characteristics of a career community according to how they define or experience it $(1=$ top-ranked characteristic). Their choices included benefits, relevance, expertise, supportive environment, reputation, specialized or personalized information, success of other members in the career community, and others.

Results indicated that $39 \%$ of the survey participants ranked benefits as their top career community characteristic, and $76 \%$ ranked this characteristic in their top three. Next was relevance (24\% top choice, $62 \%$ top three). Expertise (14\% top choice, $57 \%$ top three), supportive environment ( $8 \%$ top choice, 32\% top three), specialized or personalized information ( $7 \%$ top choice, $22 \%$ top three), reputation (5\% top choice, $24 \%$ top three), and success of other members (3\% top choice, $28 \%$ top three) followed. 


\section{Discussion}

\subsection{Defining Career Communities}

Based on previous literature, including learning communities and communities of practice, for the purposes of this paper, a general community was defined as a group of people who share a common purpose and sense of belonging. A career community was defined more specifically as a group of people with shared career interests. To narrow the definition and characteristics of a career community, two research questions were posed: 1) How do you define career community? and 2) What characteristics of a career community do you identify that might differ between communities in general versus a specific career community?

For RQ1, the results show that students have specific definitions in mind for career communities that are separate from how they may define communities in general. For general communities, students gave examples of social, academic, and ethnic communities. They even used these general terms to define community common to the previous literature, including people, goals, purpose, and sense of belonging.

For career communities, while themes were consistent with the original definition of membership, including similar career interests, more specific themes revealed themselves. It was not enough to share interests. A career community also needed to be highly customized to the student and exclusive in its membership. Participants also referenced a hierarchy and information asymmetry, where information flowed either from an expert to community members or between members in a way that is similar to that of learning communities and communities of practice. Not all members were necessarily equal, and they should not be. Lastly, the community had to contain exclusive information on the career interest of its members as opposed to providing information that could be found elsewhere. This requirement is similar to that found in a community of practice. Together, these constructs helped provide a specific benefit to members, which was also identified as an important part of the career community definition.

RQ2 asked what characteristics were identified as part of a career community. General communities included characteristics pointed out in the previous literature, such as emotional safety, common purpose, and membership. On the other hand, career communities, in line with the definition of them, have unique qualities, including a clear identifiable benefit to members, relevant, valuable information available, and expertise among the community members. Again, these traits reflect some characteristics of a learning community (i.e., the information exchange that takes place in classes) and communities of practice (i.e., social learning).

Based on the findings of this study in relation to the previous literature, we narrow the definition of career communities to the following: a group of individuals who share similar career interests or aspirations wherein one can receive direct or indirect customized career benefits through the exchange of knowledge, expertise, and resources. This type of community, if fostered in a classroom, could be seen as a learning community, or if formed more informally, it could be considered a subcategory of a community of practice.

Table 4. Summary of the Community Constructs from Qualitative and Quantitate Methods in Rank Order

\begin{tabular}{lll}
\hline Category & Focus Groups and Interviews & Survey \\
\hline General & Members / Membership & Fit / Sense of Belonging \\
Communities & Accessibility / Proximity & Common Interests \\
& Fit / Sense of Belonging & Members / Membership \\
& Emotional Safety / Trust & Emotional Safety / Trust \\
& & Accessibility / Proximity \\
Career & Beneficial & \\
Communities & Expertise & Beneficial \\
& Specialized and Personalized & Relevance \\
& Information & Expertise \\
& Success of Others & Supportive Environment \\
& Relevance & Reputation \\
\hline
\end{tabular}




\subsection{Implications for Practice}

This narrowed definition of a "career community" deserves further scholarly research. The construct of career communities evokes certain values and expectations from participants that are not elicited in general communities. Future research should delve more into defining the characteristics, values, and expectations of career communities to fully define their conceptual nature. If career communities are created with the valued characteristics (e.g., benefit, relevance, expertise), then they have the potential to increase interaction and connections among students, which in turn could lead to finding meaningful career opportunities. For example, who are considered experts? If the appropriate experts are providing resources and information in a community setting, then students may be more likely to engage in and reach their career educational goals.

Practical implications for university career services professionals are twofold. First, career communities can be an integral piece of the puzzle in increasing educational outcomes and first destination outcomes (i.e., students placed in the opportunity they desire after higher education) if they are carefully created to include the career community characteristics. This consequence is also more aligned with the community building that is common in higher education. Career services should make sure to carefully curate a community member list that includes a variety of stakeholders (e.g., alumni, employers, professors, students). However, the community should show focused relevance to its shared interest (e.g., major, career field). It should also show results and benefits of others who have been part of the community.

Creating these communities can be resource intensive, and scalability of such communities is another potential area for future research. One way to take advantage of a career community in a less resource-intensive way is for university career services to emphasize the characteristics of career communities that are highly ranked by students: benefits, relevance, and expertise. For example, testimonial statements could be provided by students that highlight positive outcomes and experiences in general content. Given the advancement of technology and access to information, especially in a university career services setting where younger generations are tech-savvy, career communities should be dynamically changing, and they need to be uniquely positioned so the value they add is clear.

This study had limitations that should be noted. A range of graduate and undergraduate students was included. Future research could further analyze career communities among diverse populations (e.g., international students, different genders, different races). It could pose, for example, questions such as what characteristics do these specific populations value, and how are they different? Furthermore, the survey was conducted and tested with a small convenience sample. Given that its purpose was to triangulate the patterns found, a larger survey sample would allow the findings to be generalizable to a population.

\section{Conclusion}

Little research exists that delves deeper in describing a "career community" in higher education and what characteristics are specific to such a community. In this study, a focused definition of career communities was developed along with associated characteristics. This outcome furthers the scholarship on communities at large. Further, by better understanding the definitions and characteristics of a career community in the context of a university setting, career services professionals can design career communities to engage students and help them achieve career and educational outcomes.

\section{References}

Allan, B. A., Owen, R. L., \& Duffy, R. D. (2017). Generation me or meaning? Exploring meaningful work in college students and career counselors. Journal of Career Development, 44(6), 502-515. https://doi.org/10.1177/0894845316667599

Battistch, V. \& Hom, A. (1997). The relationship between students' sense of their school as a community and their involvement in problem behaviors. American Journal of Public Health, 87(12), 1997-2001. https://doi.org/10.2105/ajph.87.12.1997

Baumeister, R. F., \& Leary, M. R. (1995). The need to belong: Desire for interpersonal attachments as a fundamental human motivation. Psychological Bulletin, 117(3), 497-529. http://dx.doi.org/10.1037/0033-2909.117.3.497

Contomanolis, E., Cruzvergara, C. Y., Dey, F., \& Steinfeld, T. (2015, November 2). The future of career services is now. National Association of College and Employer Journal. Retrieved from http://www.naceweb.org/career-development/trends-and-predictions/the-future-of-career-services-is-now/

Creswell, J. W. (2009). Research design: qualitative, quantitative, and mixed methods approaches. 4th ed. Thousand Oaks, CA: SAGE Publications. 
DeNeui, D. (2003). An investigation of first-year college students' psychological sense of community on campus. College Student Journal, 37(2), 224-234.

Dey, F. \& Cruzvergara, C. Y. (2014). Evolution of career services in higher education. New Directions for Student Services, 148, 5-18. https://doi.org/10.1002/ss.20105

Gherardi, S., Nicolini, D., \& Odella, F. (1998). Towards a social understanding of how people learn in organizations. The notion of a situated curriculum. Management Learning, 29, 273-297. https://doi.org/10.1177/1350507698293002

Lave, J. \& Wenger, E. (1991). Situated learning: Legitimate peripheral participation. Cambridge: Cambridge University Press. https://doi.org/10.1017/CBO9780511815355

Lee, J. Y. \& Patel, S. J. (in press). Innovating business model in the higher education industry: A platform-based approach in university career services. Industry and Higher Education. Retrieved from https://papers.ssrn.com/sol3/papers.cfm?abstract_id=3393099

Lenning, O. T., \& Ebbers, L. H. (1999). The Powerful Potential of Learning Communities: Improving Education for the Future. ASHE-ERIC Higher Education Report, 26(6). ERIC Clearinghouse on Higher Education, One Dupont Circle, NW, Suite 630, Washington, DC 20036-1183.

Lindlof, T. R. \& Taylor, B. C. (2000). Qualitative communication research methods. 3rd ed. Thousand Oaks, CA: SAGE Publications.

McCarthy, M., Pretty, G., \& Catano, V. (1990). Psychological sense of community and student burnout. Journal of College Student Personnel, 31(3), 211-216.

McMillan, D. W. \& Chavis, D. M. (1986). Sense of community: A definition and theory, Psychological Sense of Community: Theory and Concepts. Journal of Community Psychology, 14(1), 6-23. ttps://doi.org/10.1002/1520-6629(198601)14:1<6::aid-jcop2290140103>3.0.co;2-i

Parker, P., Arthur, M. B., \& Inkson, K. (2004). Career communities: a preliminary exploration of member-defined career support infrastructure, Journal of Organizational Behavior, 25(4), 489-514. https://doi.org/10.1002/job.254

Resnick, M. D., Bearman, P. S., Blum, R. W., Bauman, K. E., Harris, K. M., Jones, J., et al. (1997). Protecting adolescents from harm: Findings from the National Longitudinal Study on Adolescent Health. Journal of the American Medical Association, 278, 823-832. https://doi.org/10.1001/jama.1997.03550100049038

Schaps, E. (2003). Creating a school community. Educational Leadership, 60(6), 31-33.

Spanierman, L. B., Soble, J. R., Mayfield, J. B., Neville, H. A., Aber, M., Khuri, L., \& De La Rosa, B. (2013). Living learning communities and students' sense of community and belonging. Journal of Student Affairs Research and Practice, 50(3), 308-325. https://doi:10.1515/jsarp-2013-0022

Steger, M. F., Dik, B. J., \& Duffy, R. D. (2012). Measuring meaningful work: The work and meaning inventory(WAMI). Journal of Career Assessment, 20(3), 322-337. https://doi.org/10.1177/1069072711436160

Van Maanen, J., \& Barley, S. R. (1984). Occupational communities: Culture and control in organizations. Research in Organizational Behavior, 6, 287-365.

Warner, S., \& Dixon, M. A. (2011). Understanding sense of community from the athlete's perspective. Journal of Sport Management, 25(3), 257-271. https://doi.org/10.1123/jsm.25.3.257

Warner, S., \& Dixon, M. A. (2013). Sports and community on campus: Constructing a sports experience that matters. Journal of College Student Development, 54(3), 283-298. https://doi.org/10.1353/csd.2013.0044

Wenger, E. (1998). Communities of practice: learning, meaning, and identity. Cambridge, UK. Cambridge University Press. https://doi.org/10.1017/CBO9780511803932

Young, J. R. (2016, October 23). Reinventing the career center. The Chronicle of Higher Education. Retrieved from https://www.chronicle.com/article/Reinventing-the-Career-Center/238107.

Zhao, C. M., \& Kuh, G. D. (2004). Adding value: Learning communities and student engagement. Research in Higher Education, 45(2), 115-138. https://doi.org/10.1023/B:RIHE.0000015692.88534.de 